\title{
The Role of Language in the Identity Formation of Transnational EFL Teachers
}

\section{El papel del idioma en la identidad de maestros de inglés transnacionales*}

\author{
Perla Villegas-Torres \\ p.villegastorres@ugto.mx \\ Irasema Mora-Pablo \\ imora@ugto.mx \\ Universidad de Guanajuato, Guanajuato, Mexico
}

This research report presents the results of a qualitative study carried out at the Universidad de Guanajuato in central Mexico. Its purpose was to examine the process of identity formation of return migrants who lived a number of years in the United States and are currently studying for a BA in TESOL in Mexico. The participants use their knowledge of the English language to be able to reinsert themselves in society once they have returned to live in the country. Through narrative inquiry using autobiographies and semi-structured interviews, the study focuses on how language might influence the way in which individuals perceive themselves. Implications on family, ethnic associations, and school experiences were found.

Key words: English as a foreign language teachers, identity, language, returnees, trans-nationals.

Este reporte de investigación presenta los resultados de un estudio cualitativo realizado en la Universidad de Guanajuato en el centro de México. El objetivo fue examinar la formación de identidad

* $\quad$ Received: October 1, 2017. Accepted: February 28, 2018.

How to cite this article (APA 6th ed.):

Villegas-Torres, P., \& Mora-Pablo, I. (2018). The role of language in the identity formation of transnational

EFL teachers. HOW, 25(2), 11-27. https://doi.org/10.19183/how.25.2.418.

This article is licensed under a Creative Commons Attribution-NonCommercial-NoDerivatives 4.0 International License. License Deed can be consulted at https://creativecommons.org/licenses/by-nc-nd/4.0/. 
Perla Villegas-Torres and

Irasema Mora-Pablo

de migrantes repatriados, quienes después de vivir en Estados Unidos actualmente estudian una licenciatura en enseñanza del inglés en México. Los participantes utilizan su conocimiento del inglés para reinsertarse en la sociedad tras su retorno al país por tiempo indefinido. A través de la investigación narrativa y utilizando autobiografías y entrevistas semi-estructuradas, el estudio se enfoca en la influencia que el idioma podría tener en la autopercepción de los participantes. Se encontraron implicaciones en la familia, asociaciones étnicas y experiencias escolares.

Palabras clave: identidad, idioma, maestros de inglés, retornados, transnacionales.

\section{Introduction}

For those Mexicans who migrate to the United States to pursue better life opportunities and do not have any option but to be absorbed by the foreign culture, defining their own identity is not a straightforward process. They cannot be easily categorized as Mexican or American, they speak two languages (which either can be a prestigious or vernacular variety), they have bicultural features on their persona, and often are discriminated against by monocultural/monolingual individuals. According to Schiller, Basch, and Blanc-Szanton (1992) transnationalism is:

The process by which migrants build social fields that link together their country of origin with their country of settlement. Transnationals develop and maintain multiple relations, take actions, make decisions that span borders; and develop identities within social networks that connect them to two or more societies simultaneously. (p. 2)

The research participants are three students from the BA in TESOL at a public university in central Mexico and also in-service English as a foreign language (EFL) teachers. The three participants are classified as sojourner-transnationals (Riccio, 2001), because they went back and forth between Mexico and the U.S. throughout their childhood. Along the years that they lived abroad, experiences in different facets of the participants such as personal, academic, and social aspects contributed to shaping their current identity. These might have an important impact on the development of their personal and professional identity. According to Vertovec (2001) identity can be defined as the way in which individuals conceive themselves, and often such perception is based on a place of origin as well as the cultural aspects linked with it. Considering this aspect, it can be foreseen that transnationals' identity is one full of complexities.

Since transnationals are able to speak two different languages (having one that is the dominant or being balanced bilinguals), and to interact and understand different cultures and people, this study seeks to understand the effects of language during the process of self-identity construction. 


\section{Theoretical Framework}

As mentioned before, this research project aims to identify the relation that exists between the concepts of language and identity in the case of EFL teachers with a transnational background. In this section, we discuss concepts such as transnationalism, identity, interculturality, and language.

\section{Transnationalism}

The nature of transnationalism involves the different sorts of relations (familial, economic, social, religious, and political) that people create and that go beyond physical and political borders. According to Vertovec (2001) transnationalism and identity are intertwined concepts, "migrants share a common identity based on features such as place of origin, culture, customs, and linguistic behaviors; the identities are negotiated within social domains that span more than one place" (p. 573). Nevertheless, considering that transnationals are a product of a dual life journey (which implies receiving constant input from two different cultures), the concepts such as culture, or linguistic behavior are not clearly delimited. Hence, the identity adopted by individuals with specific migration experiences and conditions might not be common in every case. Since transnationals are continuously dealing with the before-mentioned dual culture, the idea of "negotiation" has a fundamental role in allowing individuals to adapt and construct their own identity according to the situation in which they are performing. Since transnationalism grants individuals opportunities to evolve and transform their self-concept, it is important to define the term identity.

\section{Identity and Interculturality}

According to Bauman (as cited in Buckingham, 2008) identity is a fluid process that can be considered as "infinitely negotiable" (p. 2) since it is continuously evolving and adding new features. In relation to this research project, the setting of transnationalism (moving from one country to another, developing the ability to function in different cultures, interacting with different people, etc.) fosters a rich variety of experiences, conditions, relationships, and variables that increase the possibilities of adding new features to the individual's self-identity by means of the already mentioned negotiation process.

Throughout this research project we intend to inquire about the participants' life experiences when migrating to the U.S., in different contexts such as familial, academic, and social. In such settings, migrants face opportunities and challenges that contribute to the formation of their self-image.

In addition, LaBarbera (2015) explains: "A number of studies have shown that the patterns of identification among migrants vary greatly, ranging from identification with one's 
country of origin, religion or mother tongue to receiving country, neither or both" (p. 3). Considering that Mexican migrants' everyday lives provide enough exposure to situations and experiences that come from American and Mexican cultures, we can say there is a probability that individuals develop feelings of belongingness towards both cultures. In fact, previous research reveals that individuals can successfully internalize or identify with more than one culture (Berry, 1990; Padilla, 1994). The development of identity involves experiences of reflexive consciousness: "individuals reflect on their experiences, self-consciously evaluate their attachment to different cultures, and introspect about what is important to them" (Devos, 2006, p. 383). Here, the term interculturality becomes important when defining the participants' identities. For different authors in the area of intercultural communication (Dervin, 2008; Holliday, 2010; Piller, 2011), interculturality implies more than seeing the construction of the self as static. They argue that interculturality is about "constructing a relationship through negotiating images of the self and the other, cultures, languages, etc." (Dervin \& Gao, 2012, p. 6). In this sense, Cornejo Espejo (2012) argues that the school should be the place where the idea of "interculturality citizenship" should be promoted. That is, cultural diversity should be recognized and action needs to take place.

The great task of the younger generations should be learning to live not only in a changing technological world, but to be capable, at the same time, to support and renew our local cultures, as well as being critical of the beliefs and ways of being themselves. (Cornejo Espejo, 2012, p. 241)

In order to carry out this process of reflection, individuals need to use language in order to communicate their ideas and thoughts to their peers. Therefore, language becomes an important element with which to relate to identity.

\section{Language and Identity}

Language is an aspect intrinsically connected to an individual's identity. As Giles (as cited in Phinney, Romero, Nava, \& Huang, 2001) argues, "in group speech can serve as a symbol of ethnic identity and cultural solidarity" (p. 137). It is often used as a medium to remind and reestablish the cultural heritage in a given group of people. Regarding this research project, the participants have lived in the U.S. for a certain number of years, and they speak English. As Bucholtz and Hall (2004) sustain, "language contributes to nationalist identity formation by providing a sense of cohesion and unity for its speakers" (p. 385). Considering the authors' views, everyday interactions offer information about the manners to reaffirm and construct identity, through migrant speakers' language choice.

As has been noted, the focus of this study is to determine how language may entail an influence for the process of identity construction in the particular context of transnationals. Previous research has considered this phenomenon. Imbens-Bailey (as cited in Phinney et 
al., 2001) studied second generation Armenian-American children. Results showed that "the bilingual subjects expressed more affinity with the Armenian community than did those who were monolingual in English" (p. 138). The author suggests that knowledge of the "heritage language may help maintain ethnic participation, which may in turn reinforce ethnic identity" (p. 138).

Mirdal and Ryynänen-Karjalainen (2004) describe how speakers project themselves with a target identification social group using a certain speech behavior, in order to receive reinforcement from such group. The authors add that "people use their linguistic resources to project an image of themselves, and use language differently to affiliate to certain social and ethnic categories" (p. 34). People use a "distinctive language to get associated with their ethnic identity" (Holmes, 1992, p. 186). On the basis of this study, transnationals have learned to interact in both languages, English and Spanish, depending on their interlocutor, and the circumstance where they operate. Notwithstanding this fact, hints of their ethnic/personal identity can be traced by means of studying the language behavior of bilingual transnationals in certain situations. Hence, language behavior will be approached in this research as a venue to better understand the process of identity construction.

\section{Research Design}

This research aims to study the process of identity construction, as well as the relation that it has with language; specifically in transnational teachers. The questions that guided this study were: (a) How do transnational EFL teachers construct their personal identity? (b) What is the role of language in this construction process? This project is part of a larger scale project funded by the SEP (Secretaria de Educación Pública) through the PRODEP (Programa para el Desarrollo Profesional Docente) program in which three universities-the Universidad de Guanajuato, the Universidad Autónoma de Tamaulipas, and the University of Texas at San Antonio- collaborated. For the purposes of this article, we will focus only on the theme related to language and the process of identity formation in transnational teachers.

\section{Qualitative Research}

The qualitative research allows establishing direct contact with people and obtaining the participants' testimony. In this case, it is fundamental to directly inquire into the transnational life-experiences of the participants. Thus, we were able to get complex and detailed information for a better understanding of the process of identity formation. Moreover, qualitative research allows to reconstruct the participants' stories, and to write them in a more flexible style maintaining the essence of their accounts. Lastly, qualitative research is more adequate when it comes to the study of social and human sciences because "it allows capturing a more human, emotional, and cultural side of the investigation" (Creswell, 2012, 
p. 40). Considering that the focus of this research project is on identity formation, we feel qualitative research is the paradigm that better suits its characteristics.

\section{Narrative Inquiry}

According to Hatch and Wisniewski (2002) in narrative inquiry the stories are used to describe human action. In this method the phenomenon is called "story" and the inquiry "narrative". Therefore, narrative inquiry is a way of understanding experience. The inquirer describes the lives of individuals, collects and tells stories about people's lives, and writes narratives of their experience (Hatch \& Wisniewski, 2002). We seek to listen to the stories from the participants and interpret them as a mean to understand the manners in which they are connected to the image that they have constructed of themselves.

\section{The Research Site}

The study took place in the Department of Languages at a public university in central Mexico. This is a public university with various campuses situated throughout the state. The Department of Languages attracts students from all over the state. For that reason, the BA in TESOL results in being one of the main options for young returning migrants who come back to the country every year, seeking opportunities to start a new life in Mexico.

\section{The Participants}

The research participants consisted of three students (Ian, Omar, and Norma) from the BA in TESOL at Universidad de Guanajuato; they are also in-service EFL teachers in different cities of the state of Guanajuato. Ian was taken to the U.S. when he was four years old and speaking only Spanish, Omar when he was a nine-month-old baby, and Norma was born in the U.S., but her family was of Mexican origin. Their ages rank from 23 to 26 years old. Their transnational status allowed them to embrace the two cultures almost simultaneously. All participants were told the purposes of the research and signed a consent letter. Their names have been changed in order to maintain their privacy.

\section{Data Gathering Techniques}

The instruments for data collection were as follows:

Autobiographies. The participants received a list of guidelines to develop an autobiography, including five main aspects:

1. The reasons that encouraged the family to migrate to the U.S. 
2. The process for learning the English language while adapting to their new life in the foreign country.

3. The family's "policy" about language use and the reasons for coming back to Mexico.

4. The motivations to make the decisions of becoming an English teacher.

5. Their first teaching experiences.

In this paper, we will not focus on aspects four and five. The purpose of having these autobiographies was twofold: First, it would help us to know more about the participants' background and experiences in both countries. Second, they would help us to design specific questions for their interview. We gave the participants the opportunity to choose the language in which they preferred to write the autobiographies, so they decided to write them either in English or Spanish.

Semi-structured interviews. The purpose of the interview was to obtain a more extended and deeper knowledge of each participant's story. The interviews were recorded with the participants' consent and subsequently transcribed to continue with the process of analysis.

\section{Procedure}

In addition to the autobiographies, the recorded interviews were transcribed to facilitate the analysis and both instruments were used to select the most noteworthy passages. The excerpts of data used in the discussion section were codified using the pseudonym with the initial of the research instrument to facilitate the analysis.

\section{Data Analysis and Findings}

\section{Language Learning}

As in the case of most migrants, participants reported that their parents moved to the U.S. while young, and they were seeking better life opportunities. These parents often take their children with them, and in other cases their descendants are born on American soil. Some children were born in Mexico, so before leaving the country they already spoke Spanish and some started their first years of education here. As soon as the migrant families manage to establish themselves in the U.S. they enroll their children in public schools, where children have to adapt to a new education system in a new language. Tinley (2006) describes the importance that learning the English language suddenly has for the migrant children 
since it is necessary to face their environment and other life's difficulties. Ian illustrates this situation in his account:

The language there was so different; many kids my age spoke my initial language but also began to speak another language which I did not understand at all. There were conversations they had which I did not understand but seemed very interesting. They would laugh and it seemed as they were having a good time so I wanted to do the same with them also. (Ian-A)

Accordingly, Ian tells his story about his initial struggles for learning the language in the school setting, when he mentions:

In school, it was much more difficult to acquire what the teachers were saying or attempted for us to learn. We had three teachers and only one of them spoke Spanish but not very fluently and not with a very native-like accent. When other classmates and I needed help trying to understand something, we would ask each other rather than asking the teacher. (Ian-A)

The previous fragment illustrates the fact that not every school in the U.S. handles the needs of migrant children in the same manner. While some schools provide special support to incorporate these students, others just accept them, treat them, and teach them as the rest of their peers. Similarly, many American schools are not prepared to receive Mexican Spanish speakers as students. As a consequence, some students may feel alienated, while others become capable of developing abilities to easily shift from one environment to the other. Zúñiga (2000) approaches the issue of English as a second language (ESL) classes devoted to provide assistance to migrant Mexican children taught by instructors whose cultural background and language is thoroughly oblivious to them. On this subject Ian reports his experience of having an ESOL (English for speakers of other languages) instructor whose knowledge of Spanish was limited:

I remember there was a helper and this person spoke Spanish, but it was kind of like [broken] Spanish, so I preferred not to have help from that person. I'd rather suggest them to help to other classmates. (Ian-I)

Despite being only around four years old, Ian could perceive that his instructor was not trained enough in the Spanish language as to become the mediator for him to enter this new English world, so he refused to take the assistance. In relation to this, Zúñiga (2000) explains Mexican migrant students achieve better academic results in American schools in which mother tongue and culture are valued.

When Spanish speaking-migrant children arrive in the U.S., the first stage of adaptation is largely determined by the experiences of language learning. According to the data, the act of confronting a new environment with unknown language and culture creates an effect that remains in the transnationals' personality throughout the years. 
Another participant, Omar, was taken to the U.S. being only nine months old, while Norma was born there. It is necessary to bear in mind that in both cases their parents/family spoke only Spanish at home. Interestingly, both participants reported that they acquired some English vocabulary even before being enrolled in an institution for early formal education. Along these lines, Omar elaborates more on this subject:

I do know that Spanish was my first language. Spanish was the language that was spoken at home. However, Spanish wasn't the only language that I was exposed to at home. We had satellite T.V. and my favorite programs were all in English. (Omar-A)

According to his comment, it is possible to notice that communications media is an important source when little children are acquiring language. As Bernal and Knight (1993) state, the process of adapting to a new culture - and thus acquiring the language - "takes place when the child's neighborhood is ethnically mixed, and the child interacts with nonminority children, but also through the public media" (p. 107). In the same vein, the opportunities of natural social interaction that descendants of Mexican migrants have with native English speaking children boost the natural process of learning the language. Omar adds to his account,

I also had some friends that I would hang out with every day to play videogames at their house or watch cartoons at my house. These friends were older; mostly in elementary and middle school, and we spoke in English to each other. I have American friends since I was very young because I was friend with the son of my parents' boss, so I'd go with him and stay the weekend sometimes and things like that. (Omar-I)

For little children growing up in the U.S., learning English is a natural process. However, formal learning at school boosts the development of more advanced language skills. Omar talks about his experience in getting enrolled in a Head Start Program which provides comprehensive early childhood education, health, nutrition, and parent involvement services to low-income children and their families (Bierman et al., 2008).

I was also enrolled in a Head Start program for migrant families. At that time this program was where I had the most exposure to English ... but I remember I already knew English at the time I was there. By the time I was in elementary school, I already had a good enough level of English ... There were two different schedules for the kids ... The short schedule was for kids who were native speakers or who had a good enough level of English and didn't have any learning problems. The second schedule was for students who spoke little or no English and also for students with disabilities. They conducted an interview before entering kindergarten to see what schedule would be assigned. At that time both of my parents were working. My mother ... asked me to "play dumb" at the interview so I would be assigned the longer schedule ... So, during the interview, I pretended that I didn't understand some of the questions. I was assigned the longer schedule. Because of this, the school would test us about once or twice a month to see what our progress was. We were taken to mobile home which 
had been adapted with computers and desks. We would put on headphones and we would listen to recordings and answer questions. (Omar-I)

Remarkably, Omar remembers that even when he already could communicate in English, entering the Head Start Program-which also functioned as a transition from preschool to elementary school—was a leap to improvement in his language learning. According to Bernal and Knight (1993) when migrant children enter school the social contact with the dominant language/culture increases. The author adds that this process carries with it some implications ranging from "the comfort with their ethnic identity to the overall quality of their education and mental health" (p. 107). In the preceding excerpt, Omar reports his being aware that his knowledge of English was good enough. However, he accepted his mother's suggestion to pretend that he could not speak English in order to take advantage of the longer schedule, and his parents were able to cover their labor hours. From this moment, the participant started to consciously and comfortably shift between identities by means of language use. Boroianu (2008) states that acknowledging the ability of functioning in two languages is an indicator of ethnic identity awareness in minority children.

Likewise, Bernal and Knight (1993) state that "the characteristics of the dominant society, and nature of minority-majority culture relations have a deep impact on the minority children during socialization and are important determinants of behavior" (p. 107). It seems that when socializing with children from different ethnicities, migrant infants learn to identify and accept certain differences, while reinforcing the image that they have about themselves. This process occurs having as a tool to communicate the use of the English language, and the entrance to formal education increases the opportunities to interact with others. In the next account, Norma narrates how her first contacts with formal language learning occurred, as well as the process of socialization.

I attended to a child care center at a very young age maybe I was two. So that means since then I was exposed to English. Santa Barbara CA. is the place where I born and where I lived. In this city like in many others in the U.S. a lot of Mexicans live. In the child-care center there was barely one American girl, at least that's why I can tell by looking at the pictures; although, the two teachers or at least one of them was American. The first year of school I was in the bilingual classroom. The teacher helped us a lot to feel belonging in the class we spoke both Spanish and English. A teacher would come with the Hispanics during class to provide individual attention, like once a week for like 40 minutes. She had a lot of flashcards with vocabulary to practice pronunciation and a bunch of easy to read books to practice reading. While my classmates, the American ones where reading Harry Potter, I was reading Twinkle Little Star. There were like 6 American children in the classroom ... Outside school my sister and I would socialize with other kids in our neighborhood, Mexican-Americans too, who with we practice English sometimes. (Norma-A) 
In contrast to the previous case, Norma reports that the predominant community in her hometown was Mexican. According to her account, while gradually being taught English, her Mexican background was valued and respected by means of the liberty in the use of her first language. Although she was aware that her American classmates were practicing more advanced readings, Norma did not experience any pressure to learn the language. As in the case of Omar, her second language learning was reinforced by natural interactions with native English speakers.

\section{Language Use at Home}

Migrants face a gradual process of acculturation throughout the years of residence in the U.S. The process results more evident in children whose background in Mexico is limited, whereas their current reality is dominated by American influences. In this sense, embracing the culture of the foreign language is often seen by parents as a threat to their ethnic identity and cultural heritage. In spite of the struggle and pressure that children initially undergo to acquire English as a second language and become functional in the host country, once young migrants are proficient enough in English, this language might displace the use of Spanish. Notwithstanding, it is common to observe parents' efforts to maintain the language, traditions, and certain values in order to preserve the ethnic culture. Parental decisions about language and culture practices have an important influence in the type of identity that young migrants develop. This section analyzes the practices of language use at home as reported by the participants. Ian describes how the issue of language use was handled at home:

My mom was very strict and she ... would say that someday we would come back [to Mexico] and we would have to be able to be adapted in here ... First, it was very strict only Spanish, and I think also that was beneficial to always keep in mind where we were from in case we were ever come back to have the language and be able to communicate with the people here in Mexico, but little by little I think it was freer, or while we were growing up we were using English and they were also learning English so, I think that was helpful for them also and like very strength Spanish, home became like a little bit more free, not always English but not always Spanish, we could always implement English whenever we wanted. (Ian-I)

In the previous comment, Ian describes how imposing the use of the Spanish language was one of the main resources his mother used to promote a feeling of belongingness towards Mexico. As Super and Harkness (1997) explain "the family is the major socializing influence on children and adolescents within a cultural context and parental attitudes are likely to be important to ethnic identity" (p. 39). Similarly, Ian's account suggests that his mother, as an immigrant, strongly persuaded the family to maintain their cultural values and language in the new country.

Within the context of Ian's family, the use of the English language is perceived as a threat to their ethnic connections to the community of origin (Falicov, 2007). However, there 
are also instances in which families maintain a more flexible attitude towards language use, as Omar explains in his account:

I even spent an entire summer one year with my grandparents in Mexico. I remember that that was the first time I ever felt independent and free to do many things. I think that that summer was when I learned the most about my generation in Mexico. I noticed that kids in the U.S. and Mexico weren't that different. We had similar interests in music, pop culture, and almost everything else that I can think of. The one difference I noticed was the Spanish that the kids used and the Spanish that my parents used. I was learning new words left and right. Mostly bad words or slang in Spanish, which to me was very cool because now I had new words to use with my friends in the U.S. that they didn't know. (Omar-A)

The latter extract reflects different aspects. First, the participant talks about a constant movement between both countries. As Zúñiga and Hamann (2009) affirm "enduring geographic mobility affects the complicated work of identity formation and affiliation" (p. 329). Besides, he expresses how when coming to spend time with his relatives in Mexico he felt identified with them. Zúñiga and Hamann mention: "Sojourners need not only learn how to negotiate this new place, but more fundamentally any new place, as they will sooner or later be headed someplace else" (p. 330). Omar also highlights the importance that the use of language had to create this feeling of empathy. Transnationalism refers to the capacity to build, understand, maintain, and reinforce a network of useful contacts and "funds of knowledge" (Moll, Amanti, Neff, \& Gonzalez, 1992). Moreover, being a transnational can be seen as an asset; they gain proficiency in the languages, culture, and ways of living in more than one national context, and therefore have "broader opportunity horizons than their mono-national peers" (Zúñiga \& Hamann, 2009, p. 334). Transnational sojourners are able to develop a dual sense of belonging when they adapt to new conditions coming back and forth between Mexico and the U.S.; "they are continuously negotiating and trying to connect to here and to there" (Smith, 1994, p. 17). Nonetheless, the matters of language use are not always shared in agreement among all the family members. Omar continues with his story,

At home, it was always Spanish with my parents and grandparents. I didn't mind it for the most part, but my sister seemed to be more reluctant to speak Spanish. She would always speak English to me, and I would reply to her in Spanish. (Omar-I)

According to his remark, his sister shows linguistic resistance, although she lives in a familiar context in which parents use and promote Spanish constantly. Despite showing a neutral stance towards language use, the participant seems concerned about his sister's attitude, as he explains adding to his account the next comment:

I also saw the other kids whose Spanish wasn't that good, and my sister also, [laughs] and I don't know I guess that I just don't want to lose it. (Omar-I) 
Interestingly, even when this participant was taken to the U.S. being only nine months old, and living there more than twenty years; Omar manifests a certain pride in his Mexican heritage. He perceives the Spanish language as a tie to maintain his ethnic culture and Mexican heritage. In this statement, the strong correlation language-identity can be detected. The knowledge of the inherited language helped to maintain ethnic participation (providing access to the ethnic community). Thus, it also reinforces ethnic identity. Moreover, Portes and Schauffler (as cited in Phinney et al., 2001) suggest that "retention of one's ethnic language can be seen as a cultural resource" (p. 138). In this manner, Omar is capable of fluently interacting both with American and Mexican peers; he does not mention any type of alienation because of having an accent either in Spanish or English, and even highlights the lack of proficiency of other Mexican Americans.

\section{Language and Ethnic Associations}

Language also has implications in transnationals' networking and ethnic association. They suffer because of their lack of proficiency in the second language. This issue also seems to stimulate associations with the ethnic group of origin in order to find support among them. With the aim of analyzing this situation, two of the participants responded when asked to what ethnic group they related the most.

The socialization literature suggests that "peers serve as important socialization agents, exerting a powerful influence on the ethnic attitudes and behaviors" ( $\mathrm{Xu}$, Shim, Lotz, \& Almeida, 2004, p. 96).

The phenomenon of transnationalism provides different opportunities to create ties with people in the two different countries. The participants who grew up going back and forth between Mexico and the U.S. relate their stories as follows:

My cousins were living like right next to we were living so we would always get together and I started meeting friends and we would go out and play and in the States they were always asking, "Oh, how's Mexico?" We can move back to the same place so I had the same friends ... we were always surrounded by the same people ... there was always experiences to share with both, when I would go to the States I shared all experiences about Mexico, and coming back to Mexico shared experiences about the States. (Ian-I)

We traveled to Mexico at least once a year since then. I was so used to changing country of residence. That for me was the normal thing . . . at the moment it was so "normal" for me ... I even had fun with it. I was not the kind of kid that worried about that particular fact of traveling back and forth like crazy ... outside school my sister and I would socialize with other kids in our neighborhood, Mexican-Americans too, who with we practice English sometimes. (Norma-A) 
The two statements above have something in common: They reflect positive attitudes towards people in Mexico-ethnic group of origin —emerging from their experiences as products of frequent interactions with Mexican fellows. Bearden and Randall (as cited in Xu et al., 2004) sustain that "communicating with peers significantly influences an adolescent's attitudes and behaviors and also helps to maintain group identity" (p. 96). Therefore, there is evidence that the ethnic-friendship networks have a direct influence on the formation of ethnic identity and the use of language. The three participants have a positive attitude towards the Spanish language and they consider it an important part of their identity:

I feel really proud of my heritage, being Mexican, that's why I don't want to lose it . . . it's something that was part of me and I didn't want to give it up. (Omar-I)

Omar's account offers a deeper insight into this phenomenon. In his case, it is possible to observe how interaction with other Mexican peers helped him to discover the similarities that they shared, as well as to rediscover and value his Mexican heritage. In other words, he became aware of his particular and enriched identity. Forehand and Deshpande (as cited in $\mathrm{Xu}$ et al., 2004) define "ethnic self-awareness as a temporary stage during which a person becomes more sensitive to his or her ethnic group membership" (p. 98). In the case of this participant this stage took place while he was visiting his friends in Mexico once a year. Considering this fact, one can appreciate that perhaps there is a correlation between ethnic associations-attitudes towards language-identity.

\section{Conclusion}

The data showed that migrants face several difficulties to learn the second language and assimilate into the new culture. Their initial clash with the new culture provokes conflicts when learning the language. Such impact leaves deep-rooted marks that remain in their identity throughout time. Small migrant children or those who were born in the U.S. learn from an early age to coexist between two different languages and cultures. When their Mexican background is respected and valued, they build positive attitudes towards their heritage culture. This is reflected when they seek to preserve their mother tongue and improve their skills in the second language. Therefore, the aspect of language learning as a variable of identity construction shows that individuals who undergo the process of migration and transnationalism are highly influenced by their life experiences when it comes to second language learning, or heritage language maintenance. Language is an important element of identity; hence the events connected to it result to be significant for the individual's construction of identity.

Also, the data suggest that the language promoted in the home of migrant families is an important determiner in the formation of identity. Parents who prompt the use of Spanish language at home have a conscious knowledge that it will help to preserve the Mexican identity in their children. They recognize that by demanding the use of Spanish from their 
children, they will preserve their Mexican identity. Nevertheless, the unconscious language behavior of traditional extended families in the U.S. also fosters positive attitudes towards the mother tongue, influencing the construction of ethnic identity. Likewise, the existent ties of affection of these extended families create positive attitudes towards the culture of origin, and thus favor the possibilities of self-identification with their ethnic group.

The phenomenon of transnationalism allows migrants to create ties with people in both countries. Interaction with other Mexican peers influences the construction of positive attitudes of transnationals towards their ethnic group of origin and promotes the assumption of this identity. The same opportunities of interaction trigger the use of Spanish as means of showing and reaffirming the shared identity. Consequently, there is evidence that the ethnic-friendship network has a direct influence on the formation of ethnic identity and the use of language. There is an interrelationship among the concepts of ethnic associationsattitudes towards language-identity.

Mobility as a product of globalization is a constant these days. The main reason for people to move to another country is to have access to better life opportunities. This research project has allowed us to inquire and explore different stories of life of young transnationals currently seeking to reintegrate in the academic and professional areas in Mexico.

The journey of migrants, who later become transnationals, is one full of struggles. The path towards the American dream represents facing adversity at any time: learning to socialize in a new society, having difficulties to communicate, adapting to a different school system, understanding new ways of life, facing frustration to learn the English language. Returning to Mexico, due to many reasons, may represent a strong impact for those who had already settled down in the U.S. and this might mean to start from zero in a country they might not even know. Additionally, Mexican peers do not always have an open and positive attitude towards returnees. Nevertheless, the struggle also yields rewards. They develop proficiency in two languages, possess cultural knowledge from two countries, and even more importantly, their identity encompasses features of their particular vivid experiences.

Since transnationals possess a rich cultural baggage and important linguistic knowledge, it is of great importance to study alternatives to channel returnees in Mexico to the EFL teaching profession with the aim of improving the current level of the English language in Mexico.

\section{References}

Bernal, M. E., \& Knight, G. P. (Eds.). (1993). Ethnic identity: Formation and transmission among Hispanics and other minorities. Albany, US: State University of New York Press.

Berry, J. W. (1990). Psychology of acculturation. In J. J. Berman (Ed.), Nebraska Symposium on Motivation: Cross-cultural perspectives (pp. 201-234). Lincoln, US: University of Nebraska Press. 
Bierman, K. L., Domitrovich, C. E., Nix, R. L., Gest, S. D., Welsh, J. A., Greenberg, M. T., \& Gill, S. (2008). Promoting academic and social-emotional school readiness: The Head Start REDI program. Child Development, 79(6), 1802-1817. https://doi.org/10.1111/j.14678624.2008.01227.x.

Boroianu, S. F. (2008). "She called me a Mexican!": A study of ethnic identity (Doctoral dissertation). University of Northern Iowa, USA.

Bucholtz, M., \& Hall, K. (2004). Language and identity. In A. Duranti (Ed.), A companion to linguistic anthropology (pp. 368-394). Malden, US: Blackwell Publishing.

Buckingham, D. (2008). Introducing identity. In D. Buckingham (Ed.), Youth, identity, and digital media (pp. 1-24). Cambridge, US: The MIT Press.

Cornejo Espejo, J. (2012). Educación, interculturalidad y ciudadanía [Education, interculturality, and citzenship]. Educar em Revista, Curitibia, Brasil, 43, 239-254. https://doi.org/10.1590/ S0104-40602012000100016.

Creswell, J. W. (2012). Qualitative inquiry and research design: Choosing among five approaches. London, UK: Sage.

Dervin, F. (2008). Métamorphoses identitaires en situation de mobilité. Turku, FI: Humanoria.

Dervin, F., \& Gao, G. (2012) Constructing a fairy tale around intercultural couplehood on Chinese television. Language and Intercultural Communication, 12(1), 6-23. https://doi.org/10.1080/147 08477.2011.630471.

Devos, T. (2006). Implicit bicultural identity among Mexican American and Asian American college students. Cultural Diversity and Ethnic Minority Psychology, 12(3), 381-402. https://doi. org/10.1037/1099-9809.12.3.381.

Falicov, C. J. (2007). Working with transnational immigrants: Expanding meanings of family, community, and culture. Family Process, 46(2), 157-171. https://doi.org/10.1111/j.15455300.2007.00201.x.

Hatch, J. A., \& Wisniewski, R. (Eds.). (2002). Life history and narrative. Washington, D.C.: Routledge. Holliday, A. (2010). Intercultural communication and ideology. London, UK: Sage.

Holmes, J. (1992). An introduction to sociolinguistics. New York, US: Routledge.

LaBarbera, M. C. (2015). Identity and migration: An introduction. In M. C. LaBarbera (Ed.), International perspectives on migration (pp. 1-13). Berlin, DE: Springer International Publishing.

Mirdal, G. M., \& Ryynänen-Karjalainen, L. (2004). Migration and transcultural identities. Strasbourg, FR: European Science Foundation.

Moll, L. C., Amanti, C., Neff, D., \& Gonzalez, N. (1992). Funds of knowledge for teaching: Using a qualitative approach to connect homes and classrooms. Theory Into Practice, 31(2), 132-141. https://doi.org/10.1080/00405849209543534.

Padilla, A. M. (1994). Bicultural development: A theoretical and empirical examination. In R. G. Malgady \& O. Rodriguez (Eds.), Theoretical and conceptual issues in Hispanic mental health (pp. 2051). Melbourne, US: Robert E Krieger Publishing. 
Phinney, J. S., Romero, I., Nava, M., \& Huang, D. (2001). The role of language, parents, and peers in ethnic identity among adolescents in immigrant families. Journal of Youth and Adolescence, 30(2), 135-153. https://doi.org/10.1023/A:1010389607319.

Piller, I. (2011). Intercultural communication. Edinburgh, UK: Edinburgh University Press.

Riccio, B. (2001). From “ethnic group” to "transnational community”? Senegalese migrants' ambivalent experiences and multiple trajectories. Journal of Ethnic and Migration Studies, 27(4), 583-599. https://doi.org/10.1080/13691830120090395.

Schiller, N. G., Basch, L., \& Blanc-Szanton, C. (1992). Transnationalism: A new analytic framework for understanding migration. Annals of the New York Academy of Sciences, 645, 1-24. https://doi.org/10.1111/j.1749-6632.1992.tb33484.x.

Smith, M. P. (1994). Can you imagine? Transnational migration and the globalization of grassroots politics. Social Text, 4(39), 15-33. https://doi.org/10.2307/466362.

Super, C., \& Harkness, S. (1997). The cultural structuring of child development. In J. W. Berry, P. R. Dasen, \& T. S. Saraswathi (Eds.), Handbook of cross-cultural psychology: Basic processes and human Development (Vol. 2, pp. 1-39). Boston, US: Allyn \& Bacon.

Tinley, A. (2006). Migración de Guanajuato a Alabama: experiencias escolares de cuatro familias mexicanas. Sociológica, 21(60), 143-172.

Vertovec, S. (2001). Transnationalism and identity. Journal of Ethnic and Migration Studies, 27(4), 573582. https://doi.org/10.1080/13691830120090386.

Zuñiga, V. (2000). Migrantes internacionales de México a Estados Unidos: hacia la creación de políticas educativas binacionales. In R. Tuirán K. (Ed.), Migración México-Estados Unidos: opciones de política (pp. 300-327). México: CONAPO.

Zúñiga, V., \& Hamann, E. T. (2009). Sojourners in Mexico with US school experience: A new taxonomy for transnational students. Comparative Education Review, 53(3), 329-353. https:// doi.org/10.1086/599356.

Xu, J., Shim, S., Lotz, S., \& Almeida, D. (2004). Ethnic identity, socialization factors, and culture-specific consumption behavior. Psychology \& Marketing, 21(2), 93-112. https://doi. org/10.1002/mar.10117.

\section{The Authors}

Perla Villegas-Torres is a student in the MA program in applied linguistics in English language teaching at the Universidad de Guanajuato. Her areas of interest are bilingualism, transnationalism, and identity formation.

Irasema Mora-Pablo is a professor at the Universidad de Guanajuato. She holds a $\mathrm{PhD}$ in applied linguistics from the University of Kent, UK. She has conducted research in bilingualism, Latino studies, identity formation and native and non-native teachers and has published chapters and articles in Mexico, the U.S., and Colombia. 